\title{
Courts and Proceedings: Some Nordic Characteristics
}

\author{
Pia Letto-Vanamo
}

\begin{abstract}
This paper will discuss the characteristics of the court system and proceedings in the Nordic countries. The analysis is based on the idea of Nordic legal systems as a group bound both by historical similarities between them and by advanced legal cooperation between different legal actors. First, the main features of socio-legal developments, legal theory and legal practices characterising Nordic legal systems are discussed. Then, ideas, methods and results of cooperation in the field of law are described. 'Nordicness' within legal and judicial institutions is highlighted with three examples. The first example concerns popular participation, especially the importance of lay judges. The second example concerns the relationship between the legislator and the judiciary and the non-existence of constitutional courts. Finally, the third example discusses the many modes of conflict resolution typical in the Nordic countries.
\end{abstract}

\section{Introduction}

There is no such thing as Nordic law, yet it is easy to refer to a Nordic legal minda concept that characterises the peculiarities of and similarities between the legal systems of the Nordic Countries. ${ }^{1}$ In fact, the Nordic countries comprise five countries with different histories and different laws. Generally speaking law is always national, even if national law itself needs not be of national origin: it can be a result of borrowing law or legal institutions from other countries or other legal systems. Also, the laws of

\footnotetext{
${ }^{1}$ Letto-Vanamo et al. (2019).

P. Letto-Vanamo ( $ه)$

University of Helsinki, Yliopistonkatu 3, 00014 Helsinki, Finland

e-mail: pia.letto-vanamo@helsinki.fi
} 
the Nordic countries are firmly based on principles that have their origin in a common European past. $^{2}$

In comparative analyses, however, Nordic legal systems are categorised as their own group. This is also my starting point, along with features of Nordic court systems and court proceedings.

The peculiarities of development seen in the Nordic systems are usually explained by reference to a certain historical delay in accepting such ideas and institutions as are considered to belong to the 'European mainstream'. For instance, the phenomena of a university-trained legal profession (with an exam) and legal science only appeared in the Nordic countries in the eighteenth or nineteenth centuries. ${ }^{3}$ Hence, it was comparatively late that so called learned law and university educated legal professionals started to have an impact on law-making and dispute resolution.

At the same time, the idea of 'Nordicness' is quite recent. Only in the nineteenth century did the idea of a specifically 'Nordic law' become popularly supplanted the old division between Danish-Norwegian law on the one hand and Swedish law (including Finland) on the other, especially as a tool to promote cooperation in the field of law. Since then, Nordic legal unity has been formed by active cooperation, through which many former differences were bridged. This cooperation started in 1872 when several prominent lawyers were invited to the first meeting between lawyers from all the Nordic countries for the purpose of formulating answers to the common challenges the Nordic countries and their laws faced at the time of early industrialisation. ${ }^{4}$

One of the main arguments put forward in favour of Nordic cooperation by those invited to this first meeting of Nordic lawyers referred to a 'common way of legal thinking ${ }^{5}$ Therefore, understanding the characteristics of Nordic legal thinking and legal practices requires considering both historical similarities between the Nordic legal systems and advanced legal cooperation.

Thus, the main features of socio-legal developments, legal thinking and legal practices characterising the Nordic Countries are discussed here first. Then, ideas, methods and results of cooperation in the field of law between the Countries are described. Nordicness within legal and judicial institutions, is highlighted with three

\footnotetext{
${ }^{2}$ The law of the Church, Canon law, was important in forming legal thinking in the Nordic countries. The Canon law scholars also played a significant role in the process of writing down local law, which mostly occurred in the twelfth and thirteenth centuries. However, the early wave of Roman law influence (that of the ius commune) did not have the same impacts as elsewhere in Europe. Roman law influence came later and indirect, mostly via (Roman-)German impacts in the Nordic legal scholarship in the nineteenth century.

${ }^{3}$ Tamm and Slottved (2009), Björne (2002).

${ }^{4}$ The inspiration for the meeting came from similar German and English institutions; H.Tamm (1972), Carsten (1973).

${ }^{5}$ Since the first meeting of Nordic lawyers in Copenhagen in 1872, these have been held every three years except for the periods between 1903-1918 and 1938-1947. The meeting in Helsinki in 2017 was attended by around 900 lawyers - judges, civil servants, practising lawyers and legal scholarsfrom all the Nordic countries. To enhance their importance for general debate on law, since the first meetings conference papers, talks and partly discussions among participants have been printed and published. See https://nordiskjurist.org/meetings/ (last visited 18th of January 2021).
} 
examples. The first example concerns popular participation, especially the importance of lay judges. The second example concerns the relationship between the legislator and the judiciary and the non-existence of the constitutional courts. Finally, the third example discusses the many modes of conflict resolution typical in the Nordic Countries.

\section{Active and 'Good' State}

As noted, comparative lawyers typically group the Nordic countries together as one legal entity or at least as a subfamily of the so-called civil law family. In fact, many quite well-known similarities exist between the Nordic countries, some of which still play a role in the development of legal institutions, practices and theory. One can speak of rather small, quite homogenous, even egalitarian ${ }^{6}$ societies. For a long time, cities in the Nordic countries were small, and a great majority of population was rural.

Social and legal, as well as procedural and judicial, cultures in the Nordic countries have therefore been characterised as determined by a peasant or rural culture. The impacts of the strong Monarchy introduced in the wake of the Lutheran Reformation in the sixteenth century cannot be neglected either. One can also speak of one-norm societies with an interplay between state and church that later could provide fruitful soil for modern, universal practices in Nordic welfare states. ${ }^{7}$

The Nordic countries and their law were modernised relatively recently, largely during the nineteenth century, with the first wave of industrialisation. In this process the state played an important role. In fact, the Nordic countries are often characterised as countries in which the borders between the state and civil society are blurred. Indeed, the concepts of state and society do seem to be interchangeable in many ways. In this, we can see at least some origins of the dominance of the Nordic idea of a 'good' state and the reasons for implementing the social state, inclinations which also characterise the Nordic legal system's approach to conflict resolution. The state is actively involved, e.g., in consumer protection, as well as many other alternatives to litigation. ${ }^{8}$

Also, more generally, a social dimension has been typical of Nordic legal theory, for example the focus on protecting the weaker party in contract law. ${ }^{9}$ At the same time, many societal and legal institutions have in a way been corporatist by nature in order to ensure representation of various social interests-for instance, boards with conflict-solving or advising functions or committees for drafting new legislation. ${ }^{10}$

\footnotetext{
${ }^{6}$ Petersen et al. (2019) and Niemi et al. (2019).

${ }^{7}$ Stenius et al. (2013).

${ }^{8}$ Bärlund et al. (2019).

${ }^{9}$ Wilhelmsson (1987); see also Bärlund et al. (2019).

${ }^{10}$ Letto-Vanamo (2014).
} 
Nordicness can also be found in the comparatively late professionalisation of the legal field. For a very long time, one could speak of non-expert or lay-dominated legal cultures. This again has defined court systems and legal procedures, but also explains at least partly why the Nordic legal mind even today is characterised by 'pragmatism' "1 _ reflected, for instance, in attitudes among judges towards their roles both in litigation and its alternatives. ${ }^{12}$ At the same time, popular involvement and a common-sense understanding of justice have, to varying degrees, been brought into court proceedings through participation by laymen, as will be discussed later in this chapter.

Even today, the public sector and public administration occupy a huge sphere and play an important role in all Nordic countries. However, their respective systems of conflict resolution between public authorities and citizens vary to a high degree. For instance, in Sweden and Finland, litigation between administration and citizen is dealt with by specific administrative courts organised in a hierarchy which differs from that of ordinary courts. The other Nordic countries, however, have no such administrative court system. For example, administrative cases in Denmark are dealt with by a plurality of different organs or boards, most of which are set up for specific administrative complaints such as taxes, social benefits, environmental protection or energy providers, while the ordinary courts (with some notable exceptions) normally have the last word in these matters. ${ }^{13}$

\section{Harmonising Law and the Legal Mind}

More detailed studies in legal institutions or in legal theory reveal not only similarities but also differences between the Nordic countries. As mentioned above, administrative courts exist in Sweden and Finland but not in other Nordic countries, while Scandinavian Realism, which played an important role in discussions on modernisation (democratisation) of court procedure and on judicial argumentation, was mostly a Swedish and Danish phenomenon.

Important principles of local law were written down in all the Nordic countries as early as in the Middle Ages. Even if many similarities can be found in their texts, significant differences arose due to local peculiarities. Hence, in order to understand how law and legal contacts developed and functioned between the Nordic countries, it is important to stress the ways in which the remains of earlier unions between the

\footnotetext{
${ }^{11}$ Uncomplicated and unformal style is partly linked to non-existence of modern civil law codification such as the French code civil (1804) or the German BGB (1900). Civil law issues, such as contract or tort law, have been regulated by more or less independent acts. Also generally, the Nordic countries have been resistant to these large-scale law projects, and have chosen to enact the necessary legislation separately in discrete statutes, many of which were drafted on the basis of Nordic initiatives and discussions.

${ }^{12}$ Esp. in so-called court annexed mediation, discussed in the Chap. 16.

${ }^{13}$ Mäenpää et al. (2019).
} 
countries are still visible. To this effect, we can talk of the western Nordic countries consisting of Denmark, Norway and Iceland, and the eastern Nordic countries consisting of Sweden and Finland. Denmark and Norway were united under the same King beginning in 1380 and remained so until 1814. Finland formed part of Sweden until 1809. The law of the Danish-Norwegian Monarchy (which also included Iceland) developed differently from that of the Kingdom of Sweden. In the late seventeenth century, Danish and Norwegian laws were unified on the basis of two major law books or codes (in principle containing basic rules in all fields of law), the Danish Code of $1683^{14}$ and the Norwegian Code of 1687 . The Norwegian Code was based on the Danish Code and superseded much of old Norwegian law. Thus, Danish and Norwegian law for centuries were in large part virtually identical. To a certain extent, the idea of common Danish-Norwegian legal thought persisted after 1814, the year Norway entered into a union with Sweden (until 1905), which it did without adopting Swedish law.

Sweden and Finland have always had a common legal basis, most notably the Swedish Code of 1734. In fact, Swedish laws remained the laws of Finland, and Swedish the official language, ${ }^{15}$ even after 1809 when Finland became an autonomous Grand Duchy (until 1917) within the Russian Empire. Still, this relationship with Russia has had a lasting impact on Finnish society as well as on social and legal thought, which may manifest in some of the differences between Finland and the other Nordic countries. For instance, attitudes towards law have been more legalistic $^{16}$ in Finland than in the other Nordic countries. Furthermore, Finland became involved in Nordic cooperation later than the other Nordic countries, only after becoming a sovereign state.

Nonetheless, strong similarities exist between Sweden and Finland, for example, in the preparation of new legislation. In Swedish legal tradition, including in judicial argumentation, preparatory works for new legislation (travaux préparatoires) play an important role, as they do in Denmark and Norway. Reference to Swedish material has often been used when drafting new Finnish legislation. Swedish models were actively followed also in reforming the Finnish court system and court procedures in the 1970s and 1980s.

It is possible that the Nordic countries might have continued two or more clearly distinct legal groups had such legal-political developments not been counterbalanced by active collaboration since the nineteenth century. This cooperation was based not only on common or similar histories and on the idea that the Nordic countries share a common idea of the law, but also on the conviction that the need for necessary legal reforms due to rapid developments in trade and commerce could best be met by common efforts. The cooperation started in the 1870s, and has perhaps been the

\footnotetext{
${ }^{14}$ See Tamm (1984).

${ }^{15}$ Today, Finland has two official languages, Finnish and Swedish; For instance, legislation is always published in both languages.

${ }^{16}$ In the so-called Russification period (during the decades before and after 1900) legalism was a concept that referred to retaining Swedish legislation that was (still) in force in Finland as a symbol of 'the rule of law'.
} 
most successful result of the so-called Scandinavian movement of the early nineteenth century, which after centuries of warfare between the Nordic countries, pleaded for unity, collaboration and friendship among the nations of the North.

All the Nordic countries were, and remain, relatively small, and many then topical questions were unknown to their scholars. Working together and using the potential from several countries was the obvious solution, and success immediately followed. The purpose of this cooperation was to find a joint Nordic approach to questions posed by industrialisation and the rapid development of international commerce. Challenges were posed inter alia by new instruments of payment and other issues attached to international trade. ${ }^{17}$

In addition to the meetings between Nordic lawyers, the harmonisation of Nordic law had its beginnings in the 1870s. Since then, active legislative collaboration has been a decisive feature in classifying the Nordic countries as a legal family closer to civil-law countries (countries with statutory law) than to so-called common law countries (countries with case law), or even as a family all to its own. This cooperation takes the form of discussions among representatives of the different countries about common, novel legal solutions, but at the same time it is left to each country's lawmakers, and thus to a political decision, whether and to what degree any such new legislation will actually be drafted and adopted in their country.

In 1962, Nordic legal cooperation acquired a written foundation in a treaty concluded in Helsinki. From a legal perspective, the Helsinki Treaty could be seen as a codification of former cooperation. ${ }^{18}$ According to the Helsinki Treaty, the Nordic countries would work for legal unity, for 'uniformity of regulation throughout the Nordic countries in as many respects as possible'. The aim is to attain the greatest possible uniformity in private law as was traditionally the scope of cooperation. However, the Treaty also mentions as a goal the promotion of unity as regards penal (criminal) law and penal sanctions.

Nor does cooperation mean that common courts or other organs have been established to create what could be called a 'Nordic common law'. ${ }^{19}$ At the same time, national lawyers, judges and law professors are free to formulate their own interpretations of the law. Court decisions, legal rules and legal literature are national; those of other Nordic countries can be cited, and regularly are, but they only serve an advisory function, in the same way as any other foreign law, or as sources of inspiration when making decisions.

Nonetheless, this 'soft' method of harmonising the law, which does not aim at unification but respects local peculiarities and wishes, has led to an impressive series of important statutes within basic fields of law such as commercial law, especially

\footnotetext{
${ }^{17}$ When the first Nordic lawyers' meeting was convened, the invitation stressed that because of a common understanding of law and of the common origin of many legal institutions, it was only natural that development of those institutions would need common action. The topics mentioned for cooperation were the law of commerce and issues of court procedure in civil and penal matters Carsten (1993).

${ }^{18}$ It has also been seen as a result of Denmark's and Norway's interest in cooperating with the European Economic Community (EEC); see further Letto-Vanamo and Tamm (2016).

${ }^{19}$ Common law here in the meaning of Patrick Glenn; Glenn (2005).
} 
common statutes on contracts and the law of buying and selling, ${ }^{20}$ but also within fields often considered more national and culturally sensitive, such as family law. ${ }^{21}$

Nordic legal collaboration is a characteristic feature of what in a broader sense could be called 'Nordic legal culture' ${ }^{22}$ — a sense of coming from and having studied the law of a Nordic country is part of a Nordic lawyer's identity. The Nordic lawyers' meetings, started in 1872, have since continued at different stages. Matters of common legal interest have remained on the agenda. At the same time, the meetings, which are in principle only conducted in Nordic languages, ${ }^{23}$ contribute to the feeling among Nordic lawyers of having more in common amongst themselves than with lawyers from other countries.

Procedural law has never been harmonised by common-Nordic statutes, but questions concerning courts, the judiciary and procedure have regularly been on the agenda of the Nordic lawyer's meetings. ${ }^{24}$ Since the first meetings, judges (especially from the supreme courts) have comprised the biggest group among the participants. National lawmakers have actively followed reforms and models from other Nordic countries, while informal and formal Nordic contacts (networks) form a natural part of courts' and judges' work. ${ }^{25}$ The Nordic Association for Procedural Law (Nordiska Föreningen för Processrätt) was founded in $1981 .^{26}$

\section{Nordicness: Popular Participation}

Legal modernisation has often been connected to the term democratisation: (legal) modernisation of the Nordic countries should happen with the help of legislation but also with the participation of the people, including the participation of laymen in dispute resolution in the courts. In Sweden, procedural law and court reforms were initiated during the nineteenth century in order to change the aristocratic model of the judiciary, and to implement modern procedural principles such as orality and so on. During the 1920s and '30s, 'democratisation of the judicial system' was one of the main goals of Swedish Social democratic legal policy. ${ }^{27}$ Still, reform of the court system and legal procedure continued in the country as late as 1948. In Norway and

\footnotetext{
${ }^{20}$ See further Bärlund et al. (2019).

${ }^{21}$ See further Lund-Andersen et al. (2019).

${ }^{22}$ Early results of Nordic legal 'identity' included the Nordic legal encyclopaedia (Nordisk Retsencyklopedi 1878-1899) and the Nordic journal Tidskrift for Retsvidenskab (today Tidsskrift for Rettsvitenskap, 1888-); There are also Nordic associations and/or yearly meetings for scholars and other lawyers within different legal fields.

${ }^{23}$ For participants from Finland, however, this means only the Swedish language.

${ }^{24}$ Boucht (1999), pp. 764-766.

${ }^{25}$ Since 1950s reports of the Nordic supreme courts' decisions have been published in Nordisk Domssamling.

${ }^{26}$ See in more details Bylander (2013); see also Bylander and Nylund (2015).

${ }^{27}$ Modéer (1999).
} 
Denmark, this had happened some years earlier, but in Finland as late as during the 1990 s, though the reform process had started two decades earlier.

In Finland, comments on and attitudes towards the court system and local, first instance dispute resolution have stressed the importance of maintaining informality and the 'Nordic peasant tradition'. Even in the 1970 and 1990s, proposed reforms for modernisation of court procedure (e.g., eliminating differences between courts and procedures in towns and in the countryside) were mainly based on Swedish examples. Later, however, Finnish reforms have been foremost justified by reference to European developments, especially obligations based on the ratification of the European Convention on Human Rights (ECHR). ${ }^{28}$

It can be said that for a very long time - and to a certain extent even today-the legitimacy of justice and judicial decisions arose from the conviction, or at least the assumption, that the courts obeyed the law (laws) and that the law was an expression of the will of the people. At the same time, the local, first-instance, courts were the main fora for conflict resolution, dealing with criminal and civil cases as well as with family law matters and various registration tasks. ${ }^{29}$ Popular control and a common sense of justice were brought into the proceedings by the participation of the panel of laymen $^{30}$ —and (state) supervision of legality by the (Parliamentary) Ombudsman. Today, however, the legitimacy of decisions is with increasing frequency sought elsewhere, inter alia, from alternatives to traditional dispute resolution in court.

Of course, the ancient, 'communal' method of conflict resolution (in rural areas) was also in use elsewhere in Europe. In other European countries, however, the abiding rule was that a judiciary with an academic education gradually came to supersede earlier modes of dispute resolution. It was only in the nineteenth century that laymen were again accepted as court members-mostly as result of the French Revolution of 1789 and the democratisation of Western European societies, courts included.

The same process also took place in Norway and Denmark, but not in Finland or Sweden. In the latter countries, participation of laymen in the administration of justice continued uninterrupted. In part, this was a result of the comparatively late modernisation of those societies, but also of the overall slow rate of change in their court systems. Some reasons were ideological-it was important to safeguard the idea of a folksy and egalitarian character of the court procedure-but in Finland finances also played a part. ${ }^{31}$

In every case, justifications for lay participation changed from time to time. References to local knowledge became fewer, while popular control and democracy gained currency. In the debates in Sweden of the first half of the twentieth century, and in Finland of the 1960s and '70s, the prevailing arguments pertained precisely to the

\footnotetext{
${ }^{28}$ See further Letto-Vanamo (2010).

${ }^{29}$ Moreover, the procedure in the court of first instance was a blend of judicial interventionism and folksy informality.

${ }^{30}$ In Swedish 'nämnd'.

${ }^{31}$ A system composed of a few circuit judges 'sitting ting' (and partly paying administrative costs by themselves) with lay panels placed little demand on the public purse.
} 
democratisation of justice and to popular control over the judiciary. Interestingly, in 2003 the Finnish Commission for Development of the Court System advocated socalled procedural justice with a more active role taken by the parties, and regarding arrangements towards court-annexed mediation, proposed that the use of lay judges be severely curtailed on the basis that lay participation could only be justified at all by reference to its very long tradition. Today, lay judges are still used in Finland, but only in (some) criminal law cases at the first-instance courts. In Sweden, however, they also participate in administrative and appellate courts. ${ }^{32}$

\section{Nordicness: Legislator Above Judiciary}

In all the Nordic countries the most important source of law-and the key instrument for legal-societal changes - has been parliamentary legislation. Thus, the most important legal actor is the legislator. The countries do not have constitutional courts, and the judiciary has not been willing to question the authority of the legislator. ${ }^{33}$ In fact, the Nordic countries are among the very few in Europe and the world that do not organise constitutional review through a special court. Nevertheless, a tradition of constitutional/judicial review exists. ${ }^{34}$ Indeed, one can speak of several models of constitutional review in the Nordic Countries. ${ }^{35}$ Differences between the models have historical bases, but the fundamental principle is the same: the parliament is the most important legal actor; it is the parliament, not the judiciary, that has the last word on the law.

Thus, Nordic judicial systems greatly respect their national parliaments as democratically chosen legislators. Furthermore, none of the Nordic supreme courts plays such a political role as do constitutional courts. At the same time, none of the supreme courts or other controlling organs possesses the competence to formally nullify parliamentary acts. Nevertheless, the non-existence of constitutional courts does not mean that Nordic legal systems do not share some features of the continental European legal tradition. For instance, key constitutional documents are written or codified even though they are supplemented by other formal acts, amendments, constitutional conventions or customary praxis.

Constitutionality is safeguarded first and foremost by mechanisms for review by the ordinary courts of the constitutionality of legislation. However, constitutional arrangements differ as to how such judicial review is organised. Denmark has no explicit constitutional provision concerning judicial review. ${ }^{36}$ Nonetheless, it tentatively recognises judicial review. Finland and Sweden have written constitutional provisions concerning judicial review, although in practice these provisions

\footnotetext{
${ }^{32}$ See also Nylund and Sunde (2019), pp. 209-210.

${ }^{33}$ Wind and Føllesdal (2009).

${ }^{34}$ Sunnqvist (2014); see also Sunnqvist (2021).

${ }^{35}$ For a brief comparative overview see Husa et al. (2019); see also Husa (2002).

${ }^{36}$ For the Danish constitutional system see Krunke (2014).
} 
are applied quite cautiously. Norway added judicial review to its constitution by a 2015 amendment.

Furthermore, a difference exists between each country's degree of 'judicial activism'. Sweden, Finland, Denmark and Iceland all are less active, whereas in Norway the Supreme Court has been playing an active role in judicial review. ${ }^{37}$ Despite any such differences, all Nordic countries share a spirit of constitutionalism and rule of law with general respect for the rules of the constitution and for the hierarchy of legal rules. This spirit is reflective of a parliamentary system that respects the will of the legislator and that endeavours to avoid conflicts between the parliament and the supreme courts, in alignment with the ideology of separation of powers and consensual democracy.

The Norwegian Constitution Act, ${ }^{38}$ adopted in 1814, is the second oldest written constitutional document in the world still in force, and the role of customary constitutional law is greater in Norway's system than in the other Nordic systems of law. Furthermore, the constitution enjoys a stronger political and cultural position in Norway $^{39}$ than in the other Nordic countries. ${ }^{40}$ To Norwegians, their constitution symbolises freedom, independence and democracy. Norway's exceptional role in the Nordic constitutional landscape is linked its active exercise of ex post control of the constitutionality of legislation.

The central actor is the Supreme Court (in Norwegian 'Hoyesterett'), which reviews whether a statute is in conflict with the constitution. This judicial task was not included in the written Constitution Act before 2015. Nevertheless, a tradition of constitutional review by the judiciary emerged as early as in the nineteenth century. In 2015 a novel provision was added to the Constitution Act, providing that '[i]n cases brought before the courts, the courts have the power and obligation to review whether Acts and other decisions by the state authorities are contrary to the Constitution'.

In more general terms, the Norwegian system is seen as a combination of the robust US-style judicial review and the Nordic parliamentary-friendly approach. The Norwegian Supreme Court does not declare an act null and void but rather sets aside the provision in question. Moreover, Norway's approach to judicial review bears little resemblance to the European constitutional court approach because the Supreme Court eliminates the legal-normative power of a provision only in the actual concrete case before the Court, although its decisions can have the practical effect that the provision loses its authority in other cases too.

Sweden has five constitutional documents. ${ }^{41}$ The Instrument of Government ${ }^{42}$ contains the basic principles of the form of government, defining government functions, fundamental freedoms and rights and elections to the parliament (in Swedish 'Riksdag'). In 1979, the Instrument of Government was reformed, and a cautious

\footnotetext{
${ }^{37}$ See in more detail Kierulf (2018).

${ }^{38}$ Kongeriket Norges grunnlov 1817 no 17.

${ }^{39}$ In contrast to Denmark, Finland and Sweden, Norway is not a European Union (EU) member.

${ }^{40}$ For more details see Husa et al. (2019).

${ }^{41}$ For a general overview, see Nergelius (2011).

${ }^{42}$ Riksdagsordning (2014:801).
} 
form of judicial review was introduced as part of the written constitution. The relevant rule stated that a court could declare a provision of a parliamentary act or a government decree to be in violation of the constitution and thus inapplicable, but only if the error was of an 'evident' nature. However, this rule-which was worded similarly to Finland's - had very little practical effect on the behaviour of the courts.

Since 2011, an act no longer needs to be in 'evident' conflict with a constitutional rule in order to be set aside by a court or other public body. Thus, '[i]f a court finds that a provision conflicts with a rule of fundamental law or other superior statute, the provision shall not be applied...' However, this reform did not precipitate a dramatic change in the role of the Swedish parliament because the provision in question also contains a second part which states that: 'In the case of review of an act of law under paragraph one, particular attention must be paid to the fact that the Parliament (the 'Riksdag') is the foremost representative of the people and that fundamental law takes precedence over other law.'

In other words, even while giving in to pressure for stronger judicial review, the Swedish system in fact sought to fuse together the traditional parliament-centred thinking and the more recent idea of separation of powers with a stronger judicial review approach. But even taking a more active role, judicial review may have less impact than advocates of these reforms might anticipate because Sweden's constitutional-political culture involving a strong role for the parliament also characterises its doctrine on sources of law. As noted, preparatory works (travaux préparatoires) to legislation are actively used by Swedish lawyers to obtain more information about the law - about the legislative will and the ratio (reasoning) for the rules under review.

The Finnish Constitution is written in a single act, ${ }^{43}$ which entered into force in $2000 .{ }^{44}$ This Constitution Act contains provisions about the principles for the exercise of public power, the organisation of the government and the relationships between the highest state organs. Additionally, the Act contains a catalogue of fundamental and human rights, which has had a great impact both in legal practice and in Finnish constitutional law scholarship.

In comparative analysis the most distinctive feature of the Finnish system is the way the constitutionality of legislation is safeguarded. The Constitution Act of 2000 empowered courts to perform judicial review of legislation. Moreover, the Act states that the courts and other public authorities are obliged to 'interpret legislation in such a manner that adheres to the Constitution, and to respect fundamental and human rights'. According to the Constitution Act (Article 106), when deciding a case the courts must give preference to the Constitution if applying a parliamentary act would be in 'evident conflict' with the Constitution Act.

Beginning in 2004, the courts have applied Article 106 in a handful of cases, but judicial review by the courts plays a minor role overall in terms of safeguarding the

\footnotetext{
${ }^{43}$ Suomen perustuslaki/Finlands grundlag 731/1999.

${ }^{44}$ See in more detail Husa (2011).
} 
constitutionality of legislation. That said, certain signs are indicative of the gradually growing constitutional role of the judiciary. ${ }^{45}$

In practice, the constitutionality of laws is examined in advance, before an act enters into force. The key actor in this process is the Finnish parliament's Constitutional Law Committee. The function of such control is to prevent bills that conflict with the Constitution being enacted. From the constitutional point of view, the Committee's main function is to consider each bill and issue opinions on their constitutionality and bearing on human rights. Although it is comprised of ordinary parliament members, the Committee operates on a non-partisan basis (there is no party-political discipline) in reporting to the parliament on constitutionality.

Further, the Committee calls upon academic experts (on the basis of constitutional convention) to advise the Committee in its examinations of the constitutionality of each bill. The Committee's reports are official statements and are respected by the parliament and by the government, which seeks to redraft the provisions of any bill the Committee finds unconstitutional before the bill passes into law. If the unconstitutionality found is significant, the bill is, in practice, withdrawn, and the government must find a different way to proceed. The Constitutional Law Committee's official statements are published, and they enjoy a special status as legal sources. Additionally, the Committee follows its own 'precedents'.

All this results in a unique system for policing the constitutionality of legislation, which combines an abstract ex ante and concrete, case-bound ex post review. The role of the Constitutional Law Committee is a significant one, as is the role of the academic experts guiding the Committee's views. Professors and other leading constitutional law scholars are regularly invited to Committee hearings: it is not uncommon for a constitutional law professor to write (and then orally present) 40 to 60 opinions per a year, which must greatly impact the interpretation and application of the Constitution and fundamental rights.

The general European trend of constitutionalising, ${ }^{46}$ as well as the strong European human rights approach, have also impacted the Nordic countries, both in legal practice and in legal scholarship. ${ }^{47}$ These impacts have been especially apparent in Finland, where application and interpretation of the rules and principles of the new Constitution of 2000 have come under active discussion. Still, the notion of a constitutional court as guardian of the constitution and its institutions is foreign to the Nordic context. Until now, the democratic systems in the North have been based on a certain degree of social stability and on ideals of continuity and consensus. Imposing an outside legal institution on the Nordic environment could have unexpected and unwanted consequences not only on Nordic constitutional practice but also on the Nordic constitutional mind.

\footnotetext{
${ }^{45}$ See further Ojanen (2009).

${ }^{46}$ See e.g. Tuori (2015).

${ }^{47}$ See e.g. Krunke and Thorarensen (2018).
} 


\section{Nordicness: The Many Methods of Conflict Resolution}

At the moment, a great variety of conflict resolution methods other than court litigation is in use in all Nordic countries. Similar trends towards alternative dispute resolution (ADR) are also visible in many other European countries. But the Nordic countries are atypical in the great variety of methods they employ, as well as the active role of their state institutions.

Legal advisory services broadly play an important role not only in preventing conflicts but also in resolving them. Legal advisory services are multifaceted; many of them are organised by state or municipal authorities, like public legal-aid offices and local-level consumer rights advisers, and funded by the public purse. Moreover, different boards issuing various types of recommendations, opinions, instructions or resolutions belong to the Nordic (lay and corporatist) legal tradition and occupy a central role in promoting access to justice. Boards are used, for instance, in insurance, labour, consumer and competition law disputes. The institution of ombudsmanincluding the Parliamentary Ombudsman, an institution with its origin in Sweden, and specialised ombudsmen - exists first and foremost for general oversight of legality but also plays a role in dispute resolution as well.

Today, there is a general trend toward increasing the incidence of conflict resolution outside the courts. This trend, however, can also be recognised in many other European countries, and different modes of ADR (alternative dispute resolution) are being promoted by the European Union as well. At the same time, there has been a transition in the Nordic countries from a system with numerous 'allinclusive' local courts to a system of fewer but more rational and effective courts with specialist judges. Registration matters pertaining to real property have been transferred to administrative authorities, and undisputed money claims (summary matters) to enforcement authorities. ${ }^{48}$

In the Nordic courts, more emphasis has been placed on alternative procedures, while the personality and professional skills of judges and their personal responsibility for decisions have been accented. Moreover, the idea of procedural justice has been emphasised. One can speak of a client-centred approach, which emphasises the judge's communicative skills and the parties' subjective experience of (procedural) justice $^{49}$ as well as the interaction between the judge and the parties. Thus, important aspects of the perception of justice are not only the impartiality and the high professional and ethical standards of the judge but also the opportunity for the parties to 'participate' in the proceedings, and the manner in which they are treated during the court procedure.

While the Nordic countries use alternatives to ordinary (judicial) dispute resolution more often, the courts still play a prominent role in the interplay between ordinary dispute resolution and its alternatives. In the Nordic countries, it is often pointed out that a functioning court system secures the feasibility of alternative dispute resolution (ADR): the option to bring matters before a court informs commitment parties

\footnotetext{
${ }^{48}$ See further Linnanmäki (2021) and Jensen (2021).

${ }^{49}$ See e.g. Ervasti (2007), Vindeløv (2007).
} 
make to achieve resolution by way of ADR. Hence, traditional court proceedings and ADR are not counterposed or mutually exclusive concepts, but function instead as complimentary, parallel systems.

Arbitration too has long been a typical dispute resolution method in business relations in the Nordic countries. Quite often civil cases are taken out of the courts and submitted to arbitration because court proceedings are perceived as too slow and devoid of expertise. The option of non-public proceedings plays an important role here too. At the same time, the use of conciliation and mediation has increased in both civil and criminal matters. This 'away from courts' trend is often explained by reference to broader movement toward individualisation and privatisation of societal and legal culture. It might also be seen as a reaction to the problems of court services, their low standard or narrow scope or the high costs and long duration of court proceedings. ${ }^{50}$

Mediation within the courts, discussed in Chap. 13, has become one of their central service functions, not merely a by-product of the traditional administration of justice. In fact, it can be understood as the courts' response to competition for clients as well as for legal power in society.

Overall, in the Nordic courts and elsewhere in the world, it remains important, for the position of courts in society as well as for development of the law, that courts still adjudicate a wide and comprehensive variety of disputes arising from every sector of society.

\section{References}

Björne L (2002) Den konstruktiva riktningen: den nordiska rättsvetenskapens historia 1871-1910. Institutet for Rättshistorisk Forskning, Lund

Boucht J (1999) De nordiska juristmötena och rättsgemenskapen i Norden. Defensor Legis 5:748775

Bylander E (2013) Nordiska Föreningen för Processrätt och det tolfte nordiska processrättsmötet. Svensk Juristtidning, pp 337-342

Bylander E, Nylund A (2015) Inledning: Temanummer: Processrätt. Tidskrift utgiven av juridiska föreningen i Finland. Juridiska Föreningen i Finland, Helsingfors, pp 395-400

Bärlund J, Moegelvang-Hansen P (2019) Contracting with a social dimension. In: Letto-Vanamo P et al (eds) Nordic Law in European Context. Springer, Cham, pp 115-133

Carsten G (1973) Hundert Jahre Nordischer Juristentag: 1872-1972. Rabels Zeitschrift für Ausländisches und Internationales Privatrecht/Rabel J Comp Int Private Law 1:80-100

Carsten G (1993) Europäische Integration und nordische Zusammenarbeit auf dem Gebiet des Zivilrechts. Zeitschrift Für Europäisches Zivilrecht 2:335-348

Ervasti K (2007) Conflicts before the courts and court-annexed mediation in Finland. Scand Stud Law 186-199

Glenn HP (2005) On common laws. Oxford University Press, Oxford

\footnotetext{
${ }^{50}$ For instance, several cases against Finland Sweden and Norway in the European Court of Human Rights have dealt with the requirement of Article 6 of the European Convention on Human Rights that a court decision must be made within a reasonable time.
} 
Husa J (2002) Nordic reflections on constitutional law: a comparative Nordic perspective. Peter Lang, Frankfurt am Main

Husa J (2011) The constitution of Finland: a contextual analysis. Hart, Oxford

Husa J (2019) Nordic constitutional mentality. In: Letto-Vanamo P et al (eds) Nordic law in European context. Springer, Cham, pp 41-60

Jensen C (2021) Small claims procedures in the Scandinavian countries. In: Ervo L et al (eds) Rethinking Nordic courts. Springer, Cham

Kierulf A (2018) Judicial review in Norway: A bicentennial debate. Cambridge University Press, Cambridge

Krunke H (2014) Constitutional identity seen through a Danish lens. Retfærd. Nordisk Juridisk Tidsskrift 4:24-40

Krunke H, Thorarensen B (eds) (2018) The Nordic constitutions: a comparative and contextual study. Hart, Oxford

Letto-Vanamo P (2010) Autonomy and heteronomy of judiciary: a historical approach. Oñati SocioLegal Series no 1

Letto-Vanamo P (2014) Judicial dispute resolution and its many alternatives: the Nordic experience. In: Zekoll $\mathrm{J}$ et al (eds) Formalisation and flexibilisation in dispute resolution. Brill, Leiden, pp $151-164$

Letto-Vanamo P, Tamm D (2016) Nordic cooperation in the field of law. In: Strang J (ed) Nordic cooperation: a European region in transition. Routledge, London, pp 93-108

Letto-Vanamo P, Tamm D (2019) Nordic legal mind. In: Letto-Vanamo P et al (eds) Nordic law in European context. Springer, Cham, pp 1-19

Linnanmäki K (2021) Mediation: a change in Finnish court culture? In: Ervo L et al (eds) Rethinking Nordic courts. Springer, Cham

Lund-Andersen I, Kronborg A (2019) Marriage and family relations. In: Letto-Vanamo P et al (eds) Nordic law in European context. Springer, Cham, pp 97-113

Modéer KÅ (1999) Den stora reformen: rättegångbalkens förebilder och förverkligande. Svensk juristtidning, pp 400-427

Mäenpää O, Fenger N (2019) Public administration and good governance. In: Letto-Vanamo P et al (eds) Nordic law in European context. Springer, Cham, pp 163-178

Nergelius J (2011) Constitutional law in Sweden. Kluwer, Alphen van den Rijn

Niemi J (2019) Promoting gender equality. In: Letto-Vanamo P et al (eds) Nordic law in European context. Springer, Cham, pp 79-95

Nylund A, Sunde JØ (2019) Courts and court proceedings. In: Letto-Vanamo P et al (eds) Nordic law in European context. Springer, Cham, pp 201-213

Ojanen T (2009) From constitutional periphery toward the center: transformations of judicial review in Finland. Nordic J Hum Rights 2:194-207

Petersen JH (2019) Nordic model of welfare states. In: Letto-Vanamo P et al (eds) Nordic law in European context. Springer, Cham, pp 21-39

Stenius H (2013) A Nordic conceptual universe. In: Haggren H et al (eds) Multi-layered historicity of the present: approaches to social science history. University of Helsinki, Department of Political and Economic Studies, Helsinki, pp 93-104

Sunnqvist M (2014) Konstitutionellt kritiskt dömande: Förändringar av nordiska domares attityder under två sekel. Institutet för rättshistorisk forskning, Stockholm

Sunnqvist M (2021) The changing role of Nordic courts. In: Ervo L et al (eds) Rethinking Nordic courts. Springer, Cham

Tamm D (1984) The Danish code of 1683: an early European code in an international Context. Scandinavian studies in law, pp 163-180

Tamm D, Slottved E (2009) The University of Copenhagen: a Danish centre of learning since 1479. University of Copenhagen, Copenhagen

Tamm H (1972) De nordiske juristmøder 1872-1972: Nordisk retssamvirke gennem 100 år. Nyt nordisk Forlag Arnold Busck, Copenhagen

Tuori K (2015) European constitutionalism. Cambridge University Press, Cambridge 
Vindeløv V (2007) Mediation: a non-model. Djøf, Copenhagen

Wilhelmsson T (1987) Social civilrätt: om behovsorienterade element i kontraktsrättens allmänna läror. Lakimiesliiton kustannus, Helsinki

Wind M, Føllesdal A (2009) Nordic reluctance towards judicial review under siege. Nordic J Hum Rights 2:131-141

Open Access This chapter is licensed under the terms of the Creative Commons Attribution 4.0 International License (http://creativecommons.org/licenses/by/4.0/), which permits use, sharing, adaptation, distribution and reproduction in any medium or format, as long as you give appropriate credit to the original author(s) and the source, provide a link to the Creative Commons license and indicate if changes were made.

The images or other third party material in this chapter are included in the chapter's Creative Commons license, unless indicated otherwise in a credit line to the material. If material is not included in the chapter's Creative Commons license and your intended use is not permitted by statutory regulation or exceeds the permitted use, you will need to obtain permission directly from the copyright holder.

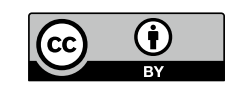

